MEQИUИHCKИE HAYKИ

\title{
WEARABLE TECHNOLOGY PROMOTES MOVEMENT PATTERN CHANGE IN UK INDUSTRIAL WORKERS.
}

Vasina Anastasiia

Postgraduate student. Physician, Sports Medicine and Exercise Therapy. Academy of molecular medicine. St-Petersburg

Smirnova Olga

National Research University Higher School of Economics. St-Petersburg DOI: 10.31618/ESU.2413-9335.2018.4.57.19-22

ABSTRACT:Low back pain imposes a significant financial burden on economies and healthcare system. In order to get a better insight into mechanical factors, it is has been recommended to investigate spine movement patterns during daily tasks. We have tested the ability of wearable technology with the feedback to change workers movement pattern. Soter Spine wearable technology together with the mobile application appeared to be effective to change the behaviour of small groups of workers.

Keywords: work-related musculoskeletal disorders, wearable technology, occupational health

\section{Introduction}

Industry constitutes a considerable a part of the manpower of most developed countries. The foremost common musculoskeletal disorders caused by manual handling are work-related low back pain and injuries. The lifetime prevalence of non-specific LBP is $60-70 \%$ in industrialized countries with an annual adult incidence of 5\% [1]. Work-related LBP accounts for $37 \%$ of LBP globally, with a two-fold variation across different geographical regions [2]. It imposes a significant financial burden on economies and healthcare system [1].

Several factors including anthropometric characteristics, the nature and severity of physical work, working postures, and methods of manual lifting/handling have been linked to the development of LBP and musculoskeletal injuries. Multifaceted etiological nature of LBP and a lack of understanding of what causes it in the absence of identifiable underlying pathology makes the management controversial. In-field assessment, therefore, may positively impact on the healthcare provision of LBP through enhanced understanding of the underlying mechanics. Ones LBP occurred it can be challenging to treat it since available treatment options are not always satisfactory [1]. Taking into account this fact together with considerable health and socioeconomic consequences, preventive interventions, therefore, are required [4].

Interventions aimed at the prevention of LBP are desirable for the workplace setting - in principle, as prevention of pain is generally preferable to its treatment and also because of the specific difficulty in treating already established LBP and the adverse effects of some analgesics that may impact alertness or cognition, and therefore safety at work. In the majority of cases, repeated or sustained positions and activities over many hours, day after day, make the musculoskeletal system more prone to injury. Therefore the analysis of biomechanics of spinal movements is required to get a better understanding where the risk comes from. In order to get a better insight of mechanical factors it is has been recommended to investigate spine movement patterns during daily tasks $[4,5]$. Continuous monitoring of spinal movement provides the opportunity for objective and quantitative assessment of kinematics and/or kinetics which provides an insight into how spine movements influence mechanical changes and hence LBP development and persistence. In this way, the link between LBP and daily activities can be assessed.

In the current study, we investigated the effectiveness of Soter Spine Ergonomic Improvement program in the industrial settings. The aim of this project was to measure the feasibility of the program to change workers behaviour and test this on a small group of workers. Soter Analytics' SoterSpine sensor continuously captured human movement data (including movement and force on the body), identified at-risk movements and notified the worker. It made the workers conscious of the impact of their working styles by giving real-time feedback, so they could minimize risky movements or avoid them.

Factors that increase the risk of injury include the load being too heavy, large, difficult to grasp or unstable, the task being too strenuous or involving awkward postures or movements. Lifting or carrying loads, awkward static posture, frequent bending and twisting proved to be the physical load risk factors consistently associated with work-related back disorders [6]. Soter Analytics' SoterSpine made the workers conscious of the impact of their working styles by giving real-time feedback, so they could minimize risky movements or avoid them. However, it was important to not only to analyse movement patterns and to make the worker aware of being at higher risk of having a musculoskeletal injury but promote changes in behaviour (reduction of the number of high-risk movements) to result in a healthier working style. Main objective was to investigate whether any behaviour change occurs during the period when the sensor is being worn and whether any behaviour change occurs or is sustained beyond the period when the sensor is worn.

\section{Methods}

SoterSpine hardware and software algorithms were developed to measure the worker's movements. Each sensor module composed by LSM6DSL Tri-axial accelerometer and gyroscope. Sensor output was transformed into meaningful parameters of rotation (twist), flexion-extension of the trunk. Feedback system con- 
sisted of the buzzer and vibration motor. Data were analysed using various techniques including machine learning (both supervised and unsupervised). Main outcome measurement was a number of high-risk movements. The high-risk movement was defined as any movement associated with an increased risk of injury. According to the main hazards described in the literature, few different types of high-risk movements were distinguished and analysed: technique (that included excessive bend and twist), prolonged static and intense movements. Poor technique was defined as making awkward bending and twisting movements, or the combination of these movements while performing work tasks. Bending angle was defined as the angle between the neutral position of the body and the current position of the body (pitch difference in the sagittal plane). The worker received notifications when performed 90 degrees bend or/ and 30-degree twist When bending angle exceeded 75 degrees and was combined with an excessive twist, it is deemed as high-risk and a notification occured. SoterSpine didn't measure the weight of objects but rather the intensity of a movement - the movement is defined as high intensive when for different reasons, the person finds it physically difficult to perform. In many cases, it contributed to working with the high load. Jerky and fast movements were also defined as high intensity.

Study design The total number of 118 industrial workers participated in the study. Written informed consents were obtained from all the subjects prior to the experiments. Subjects wore sensors during their working days for 4 weeks. SoterSpine sensors were clipped on the upper part of the T-shirt of all the workers at the level of C7-T1 vertebrae. Right placement was critical for the accurate detection of the High-Risk Movements. Inclusion criteria were adults from 18 years old, performing working tasks that involve some element of manual work. Workers were randomly divided into 3 groups: the 2 experimental groups ("device and app" group, "only device" group) and the control "no app no device" group.

Participants wore the sensors for a total of 4 workings weeks, with data being collected continually during the working day on their postures and movements. After 4 weeks participants were asked again to answer questions about current pain locations and intensities and current work risks. Device and App group had 83 participants included. Workers from the "device and app" group used SoterSpine devices together with the app. SoterSpine Improvement Ergonomic program was delivered to each worker through the mobile app. Participants worked through a series of tutorials and activities with the desired outcome of reducing the number of high-risk movements made over the duration. This was a combination of the device alerting worker after each high-risk movement and reading the tutorials to increase their knowledge and their own embodiment. According to the program, workers didn't receive the notifications about performed high-risk movements in the first day of wearing the device. However, the data were recorded and the baseline number of the high-risk movements was measured. After the first-day notifications on the device were enabled. Notifications were in the form of the beep and vibration and differed for the different types of the risk. In the very last day of the program, workers haven't received the notifications in order to investigate the improvement in comparison to baseline measurements. During all the program workers could check the number of high-risk movements performed and analytics in the mobile app. Workers from the "only device" group (total number 13) had the softer spine sensors, that continuously captured data and notified them about high-risk movements during the working day. However, they did not have access to the app, so could not see any analytics and the tutorials. In the first day of wearing the device workers from "only device" group have not got any notifications. From the second day, notifications were enabled and in the very last day of the program disabled again, in order to enable comparison of the baseline and end of the program measurement. Data from the sensors were delivered to the server. Participants from the control "no device no app" group (total number 22) were wearing SoterSpine sensor without any notifications during the whole length of the study. They have also filled the questionnaire about musculoskeletal pain in the beginning and at the end of the study.

Data storage and processing: Data were transferred from the device via Bluetooth on the mobile phone or tablet and then to the server via HTTPS.

\section{Data analysis}

Results of the study were developed using descriptive statistics: number (n), \%, (mean), Me - median, and standard deviation (SD). Both parametric and nonparametric tests were used to analyze the variables. The student's t-test was used for independent variables. Results of the study were developed using descriptive statistics: number (n), \%, (mean), Me - median, and standard deviation (SD). The correlation of two variables with a normal distribution was determined with the Pearson's linear correlation coefficient, and for the variables that did not meet the criterion of the normality of distribution, the Spearman rank correlation coefficient was calculated. Results

From the 118 participants enrolled in the study 2 failed to complete the study due to the lack of compliance (one person from the control group and one from the device group). Total number of 12 people (device only group), 21 (control group) and 88 (device and app group) were included in the analysis. Descriptive characteristics of the study sample are shown in Table 1. There was a differences between "Device and App" and "Control" groups $(-3.60 \pm 0.02$ vs $0.41 \pm 0.25, \mathrm{p}=0.01)$. Differences "Device only" and "Control" groups ($0.71,0.41 \pm 0.25, \mathrm{p}=0.63)$ in the average High-Risk Movements (HRM) per hour reduction were not significant. Differences between groups in the average HighRisk Movements (HRM) per hour reduction are presented in Table 2. There was an average correlation ( $\mathrm{r}=-$ $0.54, \mathrm{p}<0.0001$ ) between baseline (session 1) average number of high-risk movements (HRM) per hour and reduction of average high-risk movement per hour number in the "Device and App" group. Correlations between high-risk Movements per hour reduction and baseline average number of high- risk movements are presented in Table 3. No correlation ( $\mathrm{r}=0.17, \mathrm{p}>0.05)$ 
was found in the "Device and App" group between high-risk movements per hour reduction and progress through the tutorials (number of tutorials that worker have read).

\section{Discussion}

In the paper, we focused on describing the design of the Soter Spine intervention program and feasibility to change the behaviour of the small group of workers. The aim was to create a clear feedback loop for the worker and then investigate if it could effectively reduce the number of high-risk movements. We also wanted to compare the behavioural change with the "only device" feedback in comparison to the "device and app" feedback. Our study investigated if wearable moving sensing and feedback technology can improve the behaviour of the small group of the worker. We argue that technology can facilitate change through the enhancing of body awareness and providing tools and skills for better body positioning. To motivate and support the performance of everyday functional activities, the use of technology in quantifying functional tasks to enhance the feeling of doing (e.g., by using step counts [7] was suggested. However, they do not provide any real-time support in performing the activity itself. While post-self-reflection on quantified activity is useful for self-management, it alone is not sufficient to relate certain movement pattern to the risk it exposes the person.Some technologies do provide real-time feedback, focusing on correcting posture and commercial sensors such as Lumo Lift, iPosture), however, they have different application area. Besides, these approaches do not address functional activity.In the rehabilitation area studies were conducted that examined the effectiveness of the wearable moving sensing and feedback technology in low back pain management. Their results have shown that real-time movement notifications led to an increased sense of control during challenging everyday tasks.

To our knowledge, only 4 studies, examined the effectiveness of digital technologies in low back pain prevention with the sample size greater than 25 people [8].

The current study was conducted on 118 workers. Groups that we have investigated were equal in average weight, height, average high-risk movements per hour. Control group was slightly older than two intervention groups and baseline average number of total movements was slightly higher in the "device and app" group.

There was the difference between groups in the reduction of the average high-risk movements per hour. Analysis of differences between groups has shown that the average number of high-risk movements was significantly reduced in the last day compared to the baseline measurement in comparison to the control group. There was no significant reduction of the number of high-risk movements in the in the " only device" group. Correlation was found between baseline average number of high-risk movements per hour and an average number of the high-risk movements reduction in the "Device and App" group, which means that the number of high-risk movements was more reduced in the people with the greater percentage of movements at the beginning of the program. The "Device and App" group have shown the highest reduction at the end of the program that might be associated with a clear explanation of the device feedback in the app, supported by metrics. Besides the tutorials in the app provided supportive information and exercises about learning how to feel where the body is in space.

Our findings are in line with the evidence that movement sensing and real-time feedback can increase body awareness and provide movement guidance [9]. It can help people understand their body movements directly in relation to functional tasks.

\section{Conclusion}

The SoterSpine wearable sensor together with the mobile app was shown to be effective in the changing movement pattern of the small group of workers and it might be applied to a larger worker's groups. Moreover, technology also can provide information to the organisation management about spinal movements, enabling them to get a better understanding of where the risk comes from. Only short-term effect of the program was investigated and follow up study is needed to analyse if the behavioural change (reduction of the number of high-risk movements) was sustained. Further investigation is needed to answer the question if the reduction of high-risk movement will result in the reduction of low back injuries and pain within the time.

\section{Literature}

1) Duthey B. Upgrade on background Paper 6.24 Low back pain - WHO

2) Punnett L, Prüss-Ütün A, Nelson DI, Fingerhut MA, Leigh J, Tak S, et al. Estimating the global burden of low back pain attributable to combined occupational exposures. American Journal of Industrial Medicine. 2005;48(6):459-69.

3) Lühmann, D., Stoll, S., Burkhardt-Hammer, T., \& Raspe, H. Prevention of relapsing backache. GMS health technology assessment. 2006; 2, Doc12.

4) Mitchell T, Osullivan PB, Burnett AF, Straker L, Smith A. Regional differences in lumbar spinal posture and the influence of low back pain. BMC Musculoskeletal Disorders. 2008;9(1).

5) Hernandez A, Gross K, Gombatto S. Differences in lumbar spine and lower extremity kinematics during a step down functional task in people with and people without low back pain. Clinical Biomechanics. 2017;47:46-52.

6) Kong Y-K, Lee S-Y, Lee K-S, Kim D-M. Comparisons of ergonomic evaluation tools (ALLA, RULA, REBA and OWAS) for farm work. International Journal of Occupational Safety and Ergonomics. 2017 Feb;24(2):218-23.

7) Duggan GB, Keogh E, Mountain GA, Mccullagh P, Leake J, Eccleston C. Qualitative evaluation of the SMART2 self-management system for people in chronic pain. Disability and Rehabilitation: Assistive Technology. 2013 Oct;10(1):53-60.

8) Papi E, Koh WS, Mcgregor AH. Wearable technology for spine movement assessment: A systematic review. Journal of Biomechanics. 2017;64:186197.

9) Vogt K, Pirrò D, Kobenz I, Höldrich R, Eckel G. Physio Sonic - Evaluated Movement Sonification as Auditory Feedback in Physiotherapy. Auditory Display Lecture Notes in Computer Science. 2010;:103-120. 
Table 1.

Main characteristics of the groups

\begin{tabular}{|l|c|c|c|}
\hline \multicolumn{1}{|c|}{ Variable } & Device \& App & Device only & Neither app nor device feedback \\
\hline Avg. Age & $38.25 \pm 11.92$ & $32.11 \pm 10.01$ & $41.04 \pm 11.66$ \\
\hline Avg Movements/hour & $62.26 \pm 37.05$ & $52.39 \pm 30.20$ & $53.86 \pm 27.05$ \\
\hline Avg Weight & $84.01 \pm 17.57$ & $79.15 \pm 11.28$ & $91.45 \pm 17.70$ \\
\hline Avg. Height & $174.60 \pm 9.28$ & $173.4 \pm 8.66$ & $175.22 \pm 9.39$ \\
\hline Avg High-risk Movements/hour & $6.27 \pm 2.35$ & $6.19 \pm 1.01$ & $6.84 \pm 4.21$ \\
\hline
\end{tabular}

Table 2.

Differences between groups in Average HRM per Hour reduction

\begin{tabular}{|c|c|c|c|}
\hline Variable & Device & Device \& App & Neither app no device \\
\hline Average HRM per Hour reduction & $-0.71 \mathrm{P}=0.64$ & $-3.60 \mathrm{P}=0.01$ & $0.41 \mathrm{P}=0.01$ \\
\hline
\end{tabular}

Table 3.

Correlations between High-Risk Movements (HRM) per hour reduction and baseline average number of HighRisk movements

\begin{tabular}{|c|c|c|c|}
\hline \multirow{2}{*}{ Variable } & Device and App Group & Device Group & No App No Device Group \\
\cline { 2 - 4 } & \multicolumn{2}{|c|}{ Reduction of Average High-Risk Movements per hour } \\
\hline $\begin{array}{l}\text { Session 1 Average High- } \\
\text { Risk Movements Number }\end{array}$ & $R=-0.5436 \mathrm{P}<0.0001$ & $\mathrm{R}=-0.168 \mathrm{NS}$ & $\mathrm{R}=-0.13 \mathrm{NS}$ \\
\hline
\end{tabular}

\title{
РАСПРОСТРАНЕННОСТЬ СКЛЕРОАТРОФИЧЕСКОГО ЛИХЕНА У ДЕВОЧЕК-ПОДРОСТКОВ В РЕСПУБЛИКЕ МОРДОВИЯ
}

\author{
Кандина Маргарита Владимировна \\ ФГБОУ ВО «МГУ им Н.П. Огарева»,г. Саранск \\ Лабзина Людмила Яковлевна \\ Канд. биол. наук, профессор кафедры биологической и \\ фармачевтической химии \\ ФГБОУ ВО «МГУ им Н.П. Огарева», г. Саранск \\ Морозова Мария Олеговна, \\ Студентка Медицинского института \\ ФГБОУ ВО «МГУ им Н.П. Огарева», г. Саранск
}

\begin{abstract}
АННОТАЦИЯ:Целью исследования являлось изучение распространнености склероатрофического лихена у девочек-подростков в Республике Мордовия. Наблюдалось увеличение количества пациентов, прошедших стационарное лечение в 2018 году. В большинстве случаев данное заболевание отмечалось на фоне урогенитальных инфекций.

ABSTRACT:The aim of the study was to study the prevalence of scleroatrophic lichen in adolescent girls in the Republic of Mordovia. An increase in the number of patients undergoing inpatient treatment in 2018 was observed. In most cases, the disease was observed on the background of urogenital infections.
\end{abstract}

Ключевые слова: склероатрофический лихен, девочки-подростки, урогенитальные инфекции, половые органы

Keywords: scleroatrophic lichen, adolescent girls, urogenital infections, genitals

Склероатрофический лихен (СЛ) - заболевание с хроническим течением, которое поражает кожные покровы человека [1]. Со временем происходит атрофия поверхности кожи. Этот процесс необратим. Чаще заболевание атакует половые органы. У детей склероатрофический лишай встречается редко, диагноз чаще ставят девочкам от 1 года до 13 летнего возрастного периода. Причинами, влияющими на появление склерозирующего лихена являются: генетический фактор, аутоиммунные болезни (псориаз и др.), инфицирование мочеполовой системы, часто склерозирующий лихен проявляется на фоне полового герпеса, нарушения в функционировании эндокринной системы (например, сахарный диабет).

У девочек заболевание начинается с дискомфорта в месте расположения вульвы и ануса в виде систематического зуда и проявления белых пятен. Склерозирующий лишай вульвы считается опасным кожным заболеванием. В редких случаях, а это $3 \%$ больных женщин и девочек, могут столкнуться с раком.

Заболевание отнесено к группе аутоимунных заболеваний с неясной этиологией.

Наиболее важными факторами в настоящее время при возникновении заболевания у девочек 